ISSN (print): 1698-6180. ISSN (online): 1886-7995

www.ucm.es/info/estratig/journal.htm

Journal of Iberian Geology 37 (2) 2011: 137-151

doi: 10.5209/rev_JIGE.2011.v37.n2.3

\title{
Biostratigraphy and paleobiogeographic affinities of the Jurassic brachiopod assemblages from Sierra Espuña (Maláguide Complex, Internal Betic Zones, Spain)
}

\author{
Bioestratigrafía y afinidades paleobiogeográficas de las \\ asociaciones de braquiópodos jurásicos de Sierra Espuña \\ (Maláguide, Zonas Internas Béticas, España)
}

\author{
J.F. Baeza-Carratalá1,*, F. García Joral' ${ }^{2}$, J.E. Tent-Manclús ${ }^{1}$ \\ ${ }^{1}$ Departamento de Ciencias de la Tierra y del Medio Ambiente, Universidad de Alicante, Campus San Vicente del \\ Raspeig s/n, 03690, Alicante, Spain \\ jf.baeza@ua.es; je.tent@ua.es \\ ${ }^{2}$ Departamento de Paleontología, Facultad de Ciencias Geológicas. Universidad Complutense de Madrid. C/ José \\ Antonio Novais, 2; 28040, Madrid. Spain \\ fgjoral@geo.ucm.es \\ *corresponding author
}

Received: 28/06/11 / Accepted: 19/10/11

\begin{abstract}
The assemblages of Early Jurassic brachiopods (Pliensbachian - Toarcian) from Sierra Espuña (Murcia Province, SE Spain) are described. This is the only area in the Internal Zones of the Betic Cordillera, corresponding to the margins of the Alborán Terrane, where Jurassic brachiopods are known to occur. In the tectonic Unit of Morrón de Totana (more southward located) assemblage MT1 of Late Pliensbachian age has been characterized. This assemblage has been subdivided into three successive sub-assemblages: MT1a (Algovianum Zone), MT1b (Emaciatum Zone, Solare Subzone) and MT1c (Emaciatum Zone, Elisa Subzone). Northward, in the Perona tectonic Unit two distinct assemblages, P1 (Latest Sinemurian - Early Pliensbachian) and P2 (Early Toarcian, Serpentinum Zone) have been recognized.

Differences between the assemblages from the two tectonic units are evident after the paleobiogeographical analysis. In the Morrón de Totana Unit, taxa with Mediterranean affinities occur. MT1 assemblage is very similar to assemblages previously known in the Eastern Subbetic as well as in other areas of the Mediterranean Province. In the Perona Unit the Mediterranean affinity of the assemblages is not so evident. P1 Assemblage consists of widely distributed taxa, lacking in the most characteristic elements of the Mediterranean Province which, however, are present in neighbouring Betic areas. P2 Assemblage belongs to the Spanish Province that develops in Western Tethys after the Early Toarcian Mass Extinction Event. The occurrence in this assemblage of Prionorhynchia aff. msougari Rousselle, until now only found in North Africa, indicates a closer connection of the Perona Unit with the African paleomargin of the Tethys than with the South Iberian paleomargin. The paleobiogeographical data suggest a more southern and marginal (close to epicontinental areas) position of the Perona Unit than the Morrón de Totana Unit.
\end{abstract}

Keywords: Early Jurassic, brachiopods, Internal Betic Zone, Malaguide, biostratigraphy, paleobiogeography 


\section{Resumen}

Se caracterizan las asociaciones de braquiópodos del Jurásico Inferior (Pliensbachiense - Toarciense) de Sierra Espuña (Murcia), único enclave en las Zonas Internas de la Cordillera Bética en la que se tiene constancia de la presencia de estos fósiles. En la Unidad tectónica de Morrón de Totana se ha reconocido una asociación (MT1) en el Pliensbachiense Superior que, a su vez, se ha subdividido en tres subasociaciones: MT1a (Zona Algovianum), MT1b (Zona Emaciatum, Subzona Solare) y MT1c (Zona Emaciatum, Subzona Elisa). En la Unidad de Perona se registran las asociaciones P1 (Sinemuriense terminal - Pliensbachiense Inferior) y P2 (Toarciense Inferior, Zona Serpentinum).

El análisis de las afinidades paleobiogeográficas de estas asociaciones permite diferenciar las dos unidades tectónicas. En la Unidad de Morrón de Totana se registran taxones con afinidad a la Provincia Mediterránea. La asociación MT1 muestra grandes coincidencias con las asociaciones reconocidas en el Subbético Oriental y otras áreas de esta provincia. En la Unidad de Perona la afinidad mediterránea de las asociaciones no es tan evidente. La asociación P1 está formada por taxones de amplia distribución geográfica, faltando elementos característicos de la Provincia Mediterránea que aparecen en áreas próximas. La Asociación P2 corresponde a la Provincia Española que se desarrolla en el Tethys Occidental tras el evento de extinción masiva del Toarciense Inferior. La presencia en esta asociación de Prionorhynchia aff. msougari Rousselle, sólo conocida con anterioridad en el norte de África, indica una relación más estrecha de la Unidad de Perona con el paleomargen africano del Tethys que con el paleomargen Sudibérico. El análisis paleobiogeográfico sugiere una posición más meridional y marginal (próxima a las zonas epicontinentales) de la Unidad de Perona respecto a la Unidad de Morrón de Totana.

Palabras clave: Jurásico Inferior, braquiópodos, Zonas Internas Béticas, Maláguide, bioestratigrafía, paleobiogeografía

\section{Introduction}

The Early-Middle Jurassic transition paleogeography of the westernmost Tethys area was characterized by two major plates separated by the Central Atlantic Ocean in a Red Sea-type stage. The northern plate one was the Laurasian and the southern one was the African Plate. The Tethys Ocean was widening to the East. The Iberian Subplate was located in the southern margin of the northern plate, structuring the South Iberian margin (MartínAlgarra and Vera, 2004), which originated the External Betic Zone during the Alpine Orogenesis, and the northwestern margin of the African plate that evolved into the External Rif Zone. In the Tethys Ocean, the AlKaPeCa Microplate (Alboran, Kabilyan, Peloritanian and Calabria; Bouillin et al., 1986), also known as Mesomediterranean plate (Martín-Algarra et al., 1992; Guerrera et al., 1993), comprises the internal zones of the Betic-Rif, Tellian, Kabylian, Calabria-Peloritanian and Southern Apennine Chains. The paleolatitude of the South Iberian paleomargin was about $30^{\circ} \mathrm{N}$, whereas the $\mathrm{AlKaPeCa}$ Microplate was probably situated at a similar paleolatitude, but more eastward (Ziegler, 1990; Bassoullet et al., 1993; Vera, 2001; Stampfli and Borel, 2004). The Tertiary tectogenesis divided this microplate in different terranes separated by the extension of the Western Mediterranean Sea: Alboran, Kabilyan, Peloritanian, and Calabria.

The Alboran Terrane comprises the internal zones of the Betic and Rif Cordilleras. It is built up by the stacking of three complexes, called from bottom to top: Nevadofilabride, Alpujarride-Sebtide and Malaguide-Ghomaride (Sanz de Galdeano, 1997). The Nevadofilabride and Alpujarride units are composed mainly of Paleozoic and Tri- assic metamorphic rocks, while the Malaguide Complex includes very low grade Paleozoic metamorphic rocks and a Meso-Cenozoic sedimentary cover. In general, the scarcity of Jurassic non-metamorphosed successions, and the intense poli-phase tectonics have hampered a detailed description of the geodynamic evolution of the Jurassic from the internal zones.

The Malaguide Complex outcropped mainly from the Málaga Province (westward) to the Murcia Province (eastward). Analogous sediments to the Malaguide Complex are also present in the northern Rif Cordillera (Morocco), where they are known as the Ghomaride Complex (Maaté, 1996). The Sierra Espuña area, in the Murcia Province (southern Spain), is probably the most extensive, less deformed and best exposed Jurassic-Cretaceous outcrop belonging to the Malaguide-Ghomaride complexes in the Internal Betic-Rif Chain (Fig. 1A).

Very few studies have been focused in the Mesozoic paleontological content of the internal zones of the AlKaPeCa Microplate due to the lack of non-metamorphic outcrops, as the Ghomaride (Maaté, 1996), or the Tell (Alméras et al., 2007). Within the Malaguide Complex, the extensive and continuous Jurassic outcrops containing macroinvertebrate fossils in Sierra Espuña are noteworthy, which give the possibility to study the ammonite fauna, providing a precise biostratigraphic framework for the Jurassic (Fallot, 1945; Peyre and Peyre, 1960; Paquet, 1969; Geyer and Hinkelbein, 1974 and Caracuel et al., 2006).

Giving continuity to the research by Caracuel et al. (2006) the aim of this paper is to study the brachiopod assemblages in the Malaguide Complex, focusing on the Early-Middle Jurassic transition outcropping in the Si- 


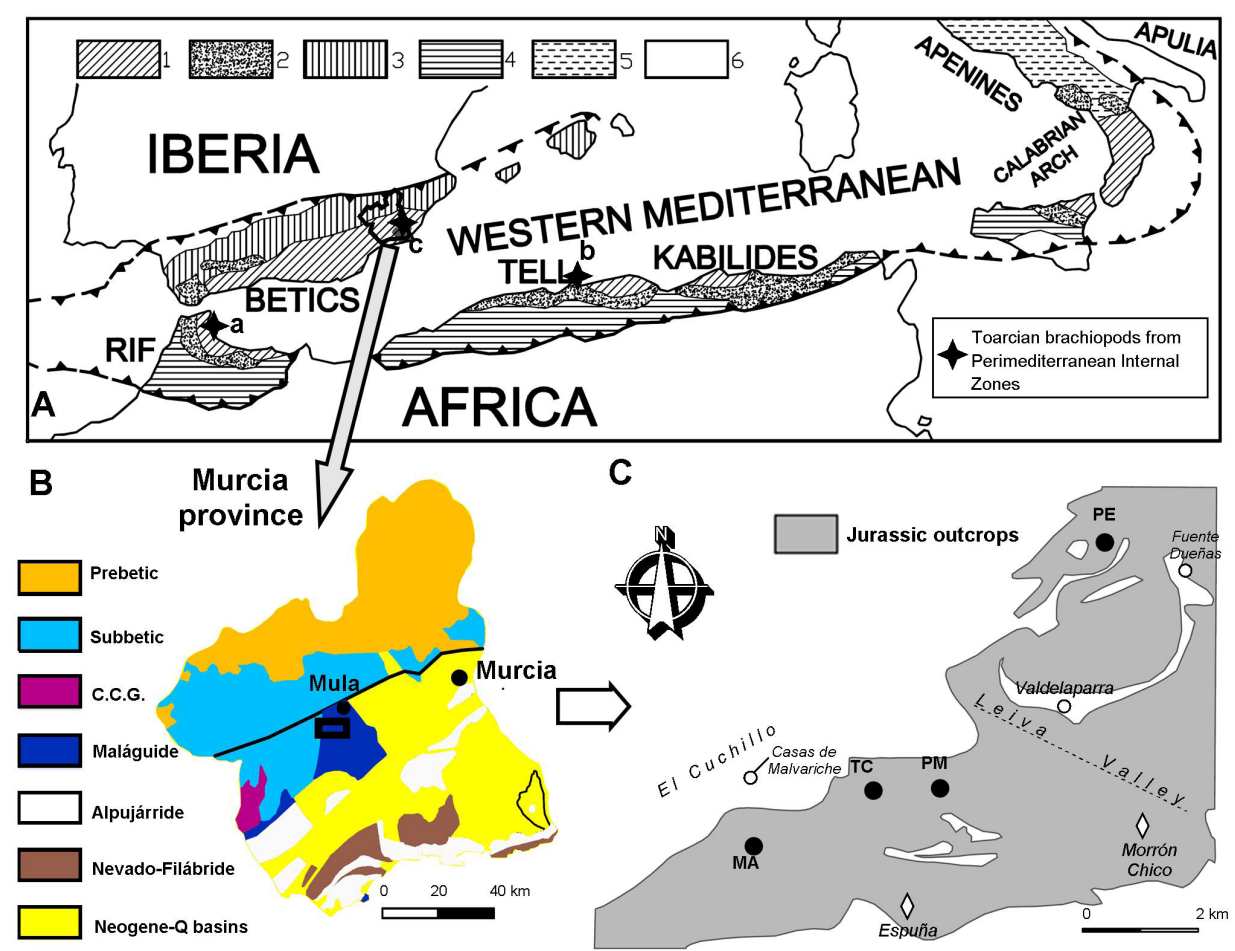

Fig. 1.- Geographical and geological setting of Sierra Espuña area. A. Sierra Espuña in the western peri-Mediterranean Alpine chains context, showing Early Jurassic brachiopod records in the Internal Zones: a. Ghomaride Complex (Maaté, 1996). b. Ouarsenis region (Alméras et al., 2007). c. Maláguide Complex (Sierra Espuña, herein); 1. Internal Zones, 2. Flysch Domain, 3. South-Iberian Palaeomargin, 4. North-African Palaeomargin, 5. Western Adriatic Palaeomargin, 6. Foreland Basins. B. Geological sketch of the Murcia province within the Betic Domains. C. Location of the sampled sections within the Jurassic outcrops from Sierra Espuña: Malvariche (MA), Tres Carrascas (TC), Prat Mayor (PM), and Perona (PE).

Fig. 1.- Marco geográfico y geológico de Sierra Espuña. A. Sierra Espuña en el contexto de las cordilleras alpinas perimediterráneas; se recogen las citas de braquiópodos en las Zonas Internas en el Jurásico Inferior: a. Complejo Ghomáride (Maaté, 1996). b. Región de Ouarsenis (Alméras et al., 2007). c. Complejo Maláguide (Sierra Espuña, nueva cita); 1. Zonas Internas, 2. Dominio de los flysch, 3. Paleomargen Sudibérico, 4. Paleomargen Nordafricano, 5. Paleomargen occidental de Adria, 6. Cuencas de Antepaís. B. Esquema geológico de la provincia de Murcia mostrando los distintos dominios de la Cordillera Bética que la conforman. C. Localización de las secciones muestreadas en los afloramientos jurásicos de Sierra Espuña: Malvariche (MA), Tres Carrascas (TC), Prat Mayor (PM) y Perona (PE).

erra Espuña area (Fig. 1B). The similarity of many of the studied taxa with those recorded in the Eastern Subbetic and other areas of the Western Tethys will also provide new criteria aiding to place more precisely these associations within the established chronostratigraphy as well as their paleobiogeographical affinities.

\section{Previous Works}

The first known reference to the brachiopods of the Jurassic of Sierra Espuña is by Fallot (1945, p. 283) who found in Prat Mayor brachiopods that he considered similar to those described in the Rincón de Egea by Jiménez de Cisneros (1923). The latter material has recently been revised by Baeza-Carratalá et al. (2004) and Baeza-Carratalá (2008, 2011), and has been assigned a probable Late Pliensbachian age. Later Peyre and Peyre (1960) recorded brachiopods also from the Prat Mayor area that were assigned to the genera Spiriferina, Terebratula and
Rhynchonella, and placed them in the "Middle Domerian" (Late Pliensbachian).

The first work in which brachiopod species are identified in Sierra Espuña is due to Paquet (1969). This author assigned to the Middle Domerian a level of red limestones with ferruginous oolites in the section of Morrón de Totana, on the basis of an abundant ammonite fauna found together with Spiriferina cf. cantianensis? Canavari, Spiriferina sp. aff. decipiens Böse and Schlosser, $S$. appenninica Canavari in Haas, $S$. falloti Corroy, $S$. cf. gibba Seguenza, Rhynchonella cf. persinuata Rau, $R$. cf. restricta Parona, $R$. quadrata Buckman, $R$. sp., Terebratula sphenoidalis Meneghini and Zeilleria sp. In the Perona area this same author (Paquet, op. cit.) reported the presence of Spiriferina ascendens Deslongchamps, $S$. gr. haueri Suess, S. falloti? Corroy, Rhynchonella curviceps Quenstedt, $R$. sp., Zeilleria roemeri Schlotheim and $Z$. cf. roemeri in red ferruginous limestones assigned to the Early Pliensbachian. 

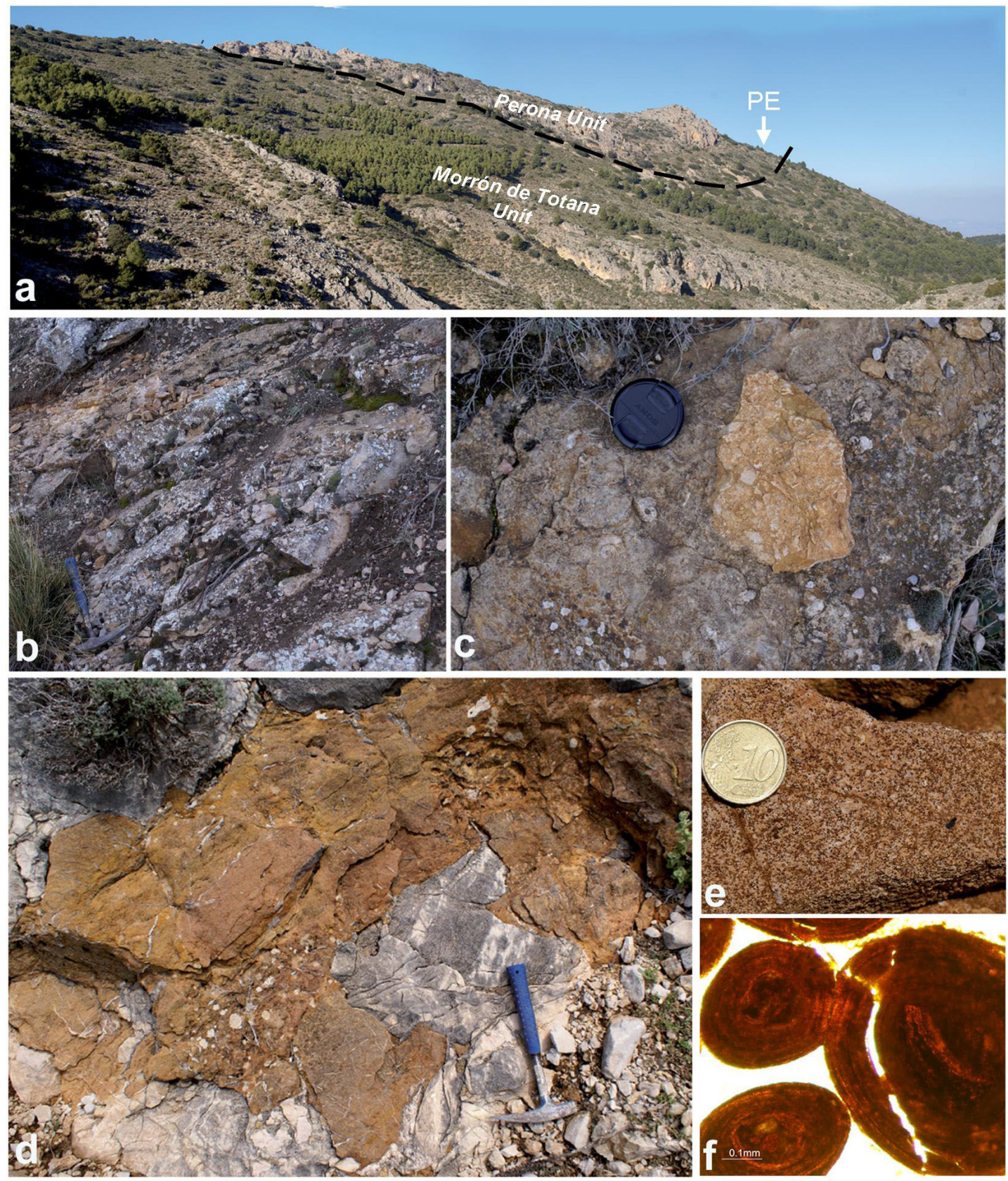

Fig. 2.- a. General view of the Morrón de Totana and Perona Units, showing the situation of the Perona Section (PE). b. Levels with ammonites and brachiopods in the Malvariche Section. c. Detail of the yellowish silty limestones in the Malvariche Section showing at the top a ferruginous-phosphated surface containing ammonites, bivalves and brachiopods. $\mathrm{d}$, e. Ferruginous oolite levels in the Tres Carrascas Section. f. Microphotographs of ferruginous oolite microfacies in the Tres Carrascas Section.

Fig. 2.- a. Panorámica del contacto entre las Unidades tectónicas de Morrón de Totana y Perona, con la localización de la sección estudiada en Perona (PE). b. Estratos con ammonites y braquiópodos en la Sección de Malvariche. c. Vista de detalle del afloramiento de calizas arenosas amarillentas con una costra ferruginosa y fosfatada suprayacente, con abundantes ammonites, bivalvos y braquiópodos en la sección de Malvariche. d, e. Capas de calizas con oolitos ferruginosos en la sección de Tres Carrascas. f. Micrografía e las microfacies de oolitos ferruginosos en la sección de Tres Carrascas.

Geyer and Hinkelbein (1974) recorded Terebratula sp. and Rhynconella wilfridi Jiménez de Cisneros in grey to yellowish limestones from the Late Pliensbachian of Prat Mayor, and Rhynchonella sp., Spiriferina angulata, and S. alpina in weakly nodular limestones and marly limestones from the Early Toarcian of Morrón de Totana.
Recently, Caracuel et al. (2006) in a biostratigraphical and paleoenvironmental study of the Sierra Espuña area based on ammonites collected numerous associated brachiopods that were stored in the Department of Earth and Environmental Sciences of the Alicante University. These brachiopods are the basis of the present study, to- 


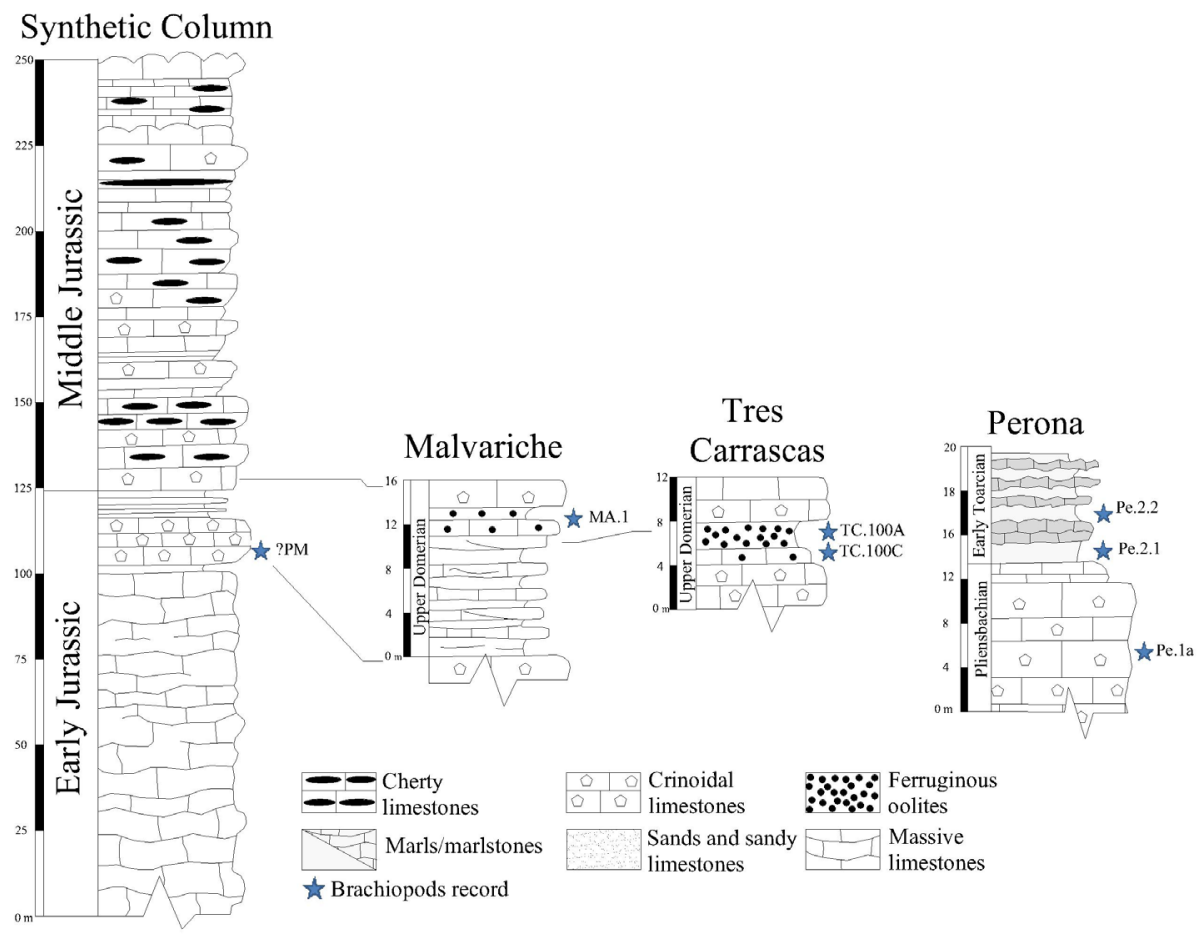

Fig. 3.- Sierra Espuña lithostratigraphical logs showing the brachiopod occurrence in the EarlyJurassic (PliensbachianToarcian). MA.1, TC.100A, TC.100C, Pe.1a, Pe.2.1, and Pe.2.2 are the beds where brachiopods were collected; ?PM level was inferred from the updated descriptions of Paquet (1969) in the Prat Mayor Section.

Fig. 3.- Secciones estratigráficas estudiadas en Sierra Espuña, conteniendo el hallazgo de niveles de braquiópodos en el Pliensbachiense-Toarciense. Las siglas MA.1, TC.100A, TC.100C, Pe.1a, Pe.2.1 y Pe.2.2 corresponden con los niveles muestreados que han librado fauna de braquiópodos; el registro ?PM se deduce a partir de la actualización de los datos de Paquet (1969) en la localidad de Prat Mayor.

gether with the newly collected specimens from the sections that Caracuel et al. (2006) called Tres Carrascas, Malvariche and Perona (Fig. 1B).

\section{Materials and Methods}

Brachiopods were collected in three stratigraphic sections which are little-tectonized and contain the most complete and fossil-rich successions: Tres Carrascas, Malvariche, and Perona (Fig. 1). The taxa reported by previous authors from the lower part of the Perona section and from Prat Mayor (Paquet, 1969; Geyer and Hinkelbein, 1974) have been also considered in this study, after an up-date of their taxonomic determinations. Taphonomic observations were considered in the Malvariche section, where the taxonomical composition of the samples is clearly biased.

The ammonite zonal/subzonal scheme follows Cariou and Hantzpergue (1997) for the Pliensbachian and Toarcian of the Mediterranean Domain. Chronostratigraphic data from Caracuel et al. (2006) in Sierra Espuña area were also considered. Facies characteristics of the beds containing the studied brachiopods were described and related to the regional stratigraphic framework. Twelve thin sections were also used for characterizing some microfacies and textures, especially from the ferruginous oolithic limestone interval. For paleobiogeographical interpretations, species representation, species richness and comparison of shared species with other basins of the Western Tethys were considered.

\section{Geological setting and facies distribution}

The Malaguide units outcropping in the Sierra Espuña area bounds tectonically with the Alpujarride Complex to the SE and with the External Betic Zones (Subbetic) to the NW (Fig. 1B).

Two tectonic units have been defined in Sierra Espuña (Martín-Martín, 1996; Martín-Martín and Martín-Algarra, 1997): Morrón de Totana Unit and Perona Unit (Fig. 2a). Both of them include Jurassic to Tertiary sediments, although in the Perona Unit only reduced extension of Liassic p.p. and Tertiary sediments are recognized.

The Early-Middle Jurassic transition sediments of Morrón de Totana Unit outcrop with lateral continuity for more than $10 \mathrm{~km}$ over a Paleozoic to Triassic succession, from the Prat Mayor area to the Malvariche Valley area. The synthetic stratigraphic succession distinguished in this unit it is shown in Fig. 3.

The lowermost rocks of Jurassic age in this succession are of dolomitic facies traditionally attributed to the Earliest Jurassic (probably Hettangian). Overlying them a thick set of oolitic-pisolitic white limestones evolving upwards to pinkish oncolitic-rodolitic limestones are present. These are sometimes massive frequently crossbedded and sometimes brecciated beds, often with thickness of ten metres. Texturally they are grainstones to packstones (occasionally rudstones). The microfacies of this portion of the section was analysed by Caracuel et al. (2006), showing algal remains, ostracods, sponges and benthic foraminifera. Kampschuur et al. (1972) suggest 


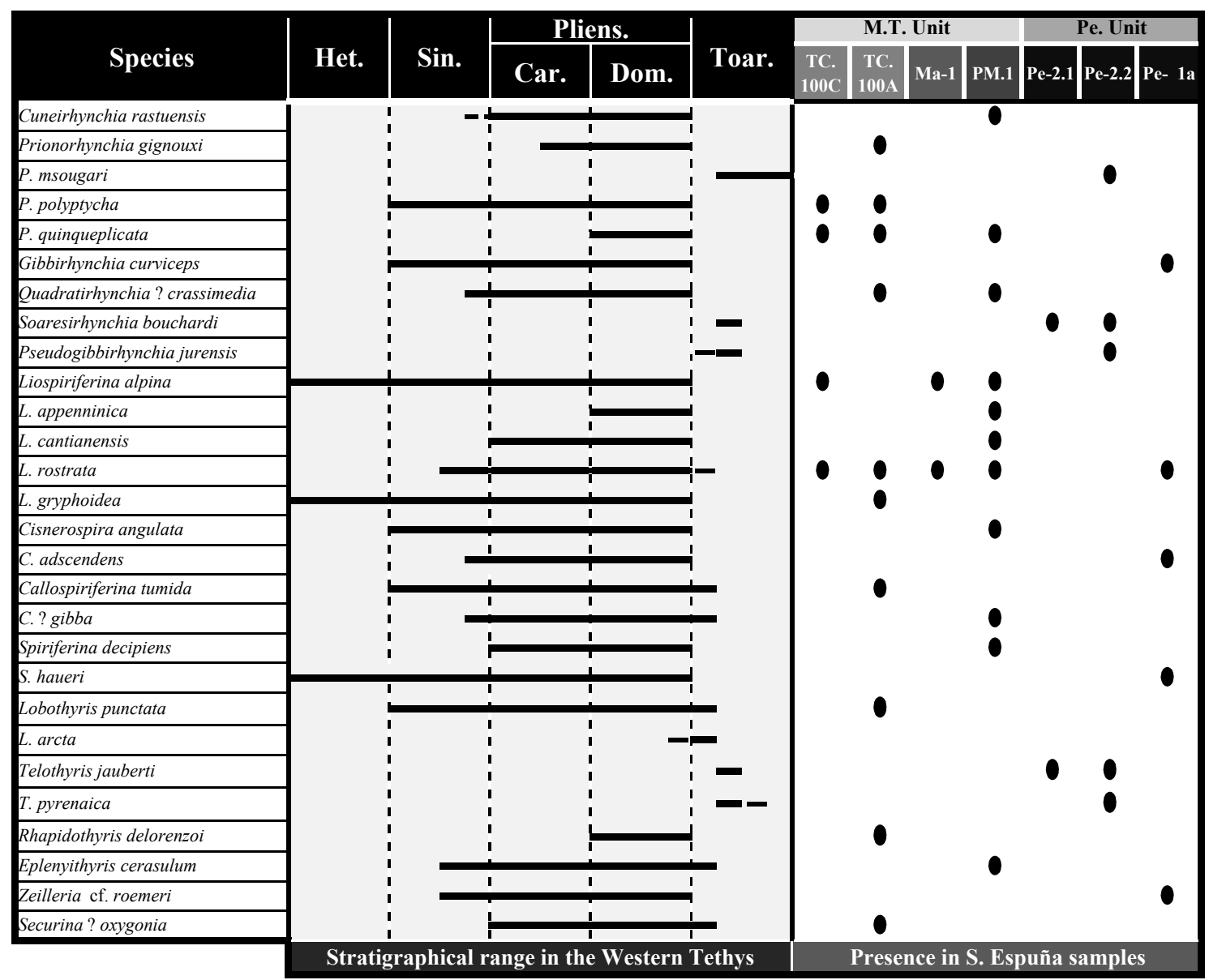

Table 1.- Detailed ocurrence of Early Jurassic brachiopod species in the Sierra Espuña studied sections and their stratigraphical distribution in the Western Tethys. The stratigraphic data were obtained from the references indicated in section 5 in the text; additional data from Alméras (1964).

Tabla 1.- Especies de braquiópodos del Jurásico Inferior registrados en los afloramientos estudiados en Sierra Espuña y su distribución estratigráfica en el Tethys Occidental. El origen de los datos de las distribuciones estratigráficas se cita en el texto, completándose con las citas de Alméras (1964).

a Sinemurian to Pliensbachian age for these limestones.

Overlying this sequence red-pinkish crinoidal grainstones are present, with intercalations in the upper part, of sandy limestones first and ferruginous oo-oncolitic limestone towards the top. The brachiopods studied in this work from Malvariche and Tres Carrascas Sections came from these sandy and crinoidal grainstones levels, characterized by a rich ammonite content indicating a Domerian to Toarcian age. The oolites/oncoids consist of concentric growth of Fe-Mn laminae around a nucleus (Fig. 2e-f). Finally, in the Middle Jurassic well-bedded micritic (oolitic in the basal levels) and crinoidal limestones facies with abundant cherty nodules prevail.

In the Perona Unit, the basal sequences of the Early Jurassic carbonate succession show generally the same facies found in the Morrón de Totana Unit: dolomitic at the base, followed by oolitic white limestones and red crinoidal limestones. However, over the crinoidal tract a set of red, ferruginous detritic limestones appear, fol- lowed by an alternation of yellowish marls and marly/ silty limestones levels with brachiopods, some ammonoids and trace-fossils of Thalassinoides type.

\section{Paleontological and biostratigraphical record}

\subsection{Preservation of the brachiopod shells.}

A total number of 438 brachiopods were studied. The detailed provenance of the brachiopods is indicated in Table 1 . Several specimens of the more representative taxa are shown in figures 4 and 5. In most localities the brachiopods are well preserved, with nearly $80 \%$ of fossils preserving the shell and showing a low degree of breakage. However, a low taxonomic diversity, high breakage and reworking is found in the Malvariche section, implying a preferential accumulation of flat and subcircular-elliptic valves such as the dorsal valves of spiriferinids and similarly shaped pectinids; the ratio of dorsal/ventral valves 
sampled is $78.95 \%$ / $21.95 \%$. In this locality, ammonoids show neomorphosed phosphated shells and sometimes with Fe-Mn oxide crusts.

Internal recrystallization of the specimens is common though not dominant in all the studied assemblages. Occasionally, juvenile specimens with ferruginous crusts are found in the Fe-oolites intervals. In the Perona section, Soaresirhynchia bouchardi specimens frequently display fosildiagenetic deformations and tectonically compressed specimens.

In most samples no size sorting was observed but occasionally some mono- or di-specific assemblages were found in Malvariche and in Perona. In the first case it is clearly a consequence of reworking, whereas in the second case the assemblages, highly dominated by Soaresirhynchia bouchardi, seem to be related to unique colonization and opportunism strategies of this species (García Joral and Goy, 2000, Gahr, 2005, Graziano et al., 2006, García Joral et al., 2011).

\subsection{Tres Carrascas Section}

The brachiopods were collected in two beds (TC.100C and TC.100A) belonging to ferruginous silty limestones with Fe-oolites (Fig. 3). In bed TC.100C, Caracuel et al. (2006) identified several ammonoids assigned to Pleuroceras solare (Phillips), Lioceratoides fucinianus (Haas), L. exaratus (Gemmellaro) and Neolioceratoides hoffmanni (Gemmellaro), indicating a Late Pliensbachian (Emaciatum Zone, Solare Subzone) age. The brachiopods collected in this bed are Prionorhynchia polyptycha (Oppel), P. quinqueplicata (Zieten), Liospiriferina cf. alpina (Oppel), L. rostrata (Schlotheim) and Terebratulidae gen. et sp. ind. All these brachiopod species are also recorded in the Eastern Subbetic (Baeza-Carratalá, 2008) within a biostratigraphic association that ranges from the Early Pliensbachian Demonense Zone to the Late Pliensbachian Emaciatum Zone. Prionorhynchia quinqueplicata occurs in the Spinatum (= Emaciatum) Zone in England (Ager, 1956), and in the "Domerian" (=Late Pliensbachian) in the Mediterranean Province (Sacchi Vialli and Cantaluppi, 1967 in Italy; Iñesta, 1988 and Baeza-Carratalá, 2008 in the Eastern Subbetic), whereas Alméras et al. (2007) reported this species in the Lavinianum-Algovianum Zones in Western Algeria.

In the second bed, TC.100A, Caracuel et al. (op. cit.) identified Emaciaticeras archimedis (Fucini), E. lottii (Gemmellaro), E. timaei (Gemmellaro), Lioceratoides serotinus (Bettoni), L. micetoi (Fucini) and Neolioceratoides hoffmanni (Gemmellaro). According to these authors, this assemblage belongs to the latest Pliensbachian (Emaciatum Zone, Elisa Subzone). The brachiopods re- corded in this bed are Prionorhynchia polyptycha (Oppel) (exceptionally large), P. quinqueplicata (Zieten), P. gignouxi (Jiménez de Cisneros), Quadratirhynchia? crassimedia (Buckman), Rhapidothyris delorenzoi (Böse), Securina? oxygonia (Uhlig), Callospiriferina tumida (von Buch), Liospiriferina rostrata (Schlotheim), L. cf. gryphoidea (Uhlig), Lobothyris cf. punctata (Sowerby) and Terebratulidae sp. indet.

As in the previous bed, some brachiopod taxa with wide stratigraphic ranges such as Prionorhynchia polyptycha, Lobothyris punctata, Liospiriferina rostrata, L. alpina, L. gryphoidea or C. tumida, are found in this level together with other taxa restricted to the Late Pliensbachian. These are Prionorhynchia quinqueplicata, Prionorhynchia gignouxi, recorded in the Subbetic in the Late Pliensbachian (Alméras et al., 1993; Baeza-Carratalá, 2008), and Rhapidothyris delorenzoi, recorded in the Spinatum Zone of the Bakony Mountains (Hungary) by Vörös (2009), and between the Lavinianum and the lowermost Polymorphum (Early Toarcian) Zones in the Subbetic of Alicante and North Murcia by Baeza-Carratalá (2010).

\subsection{Malvariche Section}

The brachiopods studied in this section were collected in yellowish sandy limestones with abundant iron oxides and phosphates. They were found together with numerous pectinids and some ammonites and belemnites. All brachiopods were identified as belonging to the genus Liospiriferina (83\% Liospiriferina alpina $+17 \%$ Liospiriferina cf. rostrata), both species presenting a wide stratigraphic range. According to Caracuel et al. (2006), the ammonite fauna in these levels is abundant, with taxa of Late Pliensbachian age (Algovianum Zone, Ragazzoni, Bertrandi and Accuratum Subzones) found together with others of a somewhat older age (Lavinianum Zone): Fuciniceras cornacaldense (Tausch), Fieldingiceras fieldingii (Reynes), and Becheiceras bechei (Sowerby).

\subsection{Prat Mayor Section}

In the locality of Prat Mayor, Paquet (1969) assigned a level of red limestones with ferruginous oolites to the "Middle Domerian" (= Algovianum Zone of the Late Pliensbachian) on the basis of an abundant ammonite fauna: Phylloceras (Partschiceras) tenuistriatum Meneghini, Lytoceras sp. aff. fimbriatoides Gemmellaro, Coeloceras (Reynesoceras) ragazzoni (Hauer), $C$. (Re.) cf. annulitiforme Bonarelli, Fuciniceras cf. curionii (Meneghini), Protogrammoceras bassanii (Fucini), Arieticeras cf. apertum Monestier, $A$. bertrandi (Kilian), $A$. 
sp. cf. delcampanai Fucini, A. cf. domarense (Meneghini), A. fuccinii Del Campana, $A$. geyeri Del Campana, $A$. lozeriense Monestier, A. macrum Monestier, A. reynesi Fucini, $A$. aff. ruthenense Reynes. Paquet (1969) also identified the brachiopods Spiriferina cf. cantianensis? Canavari, S. sp. aff. decipiens Böse and Schlosser, S. appenninica Canavari in Haas, $S$. falloti Corroy, $S$. cf. gibba Seguenza, Rhynchonella cf. persinuata Rau, $R$. cf. restricta Parona, R. quadrata Buckman, R. sp., Terebratula sphenoidalis Meneghini, and Zeilleria sp. This fauna is comparable to the fauna recorded in the Eastern Subbetic in the Late Pliensbachian - Earliest Toarcian, and have been updated as follows (cf. Baeza-Carratalá, 2008): Spiriferina gibba $=$ Callospiriferina gibba; $S$. falloti $=$ Liospiriferina rostrata; $S$. appenninica $=$ L. appenninica; $S$. cantianensis $=L$. cantianensis; Terebratula sphenoidalis $=$ Phymatothyris cerasulum $(\mathrm{Zittel})(=$ Eplenyithyris cerasulum after Vörös, 2009); Rhynchonella cf. persinuata $\mathrm{Rau}=$ Cuneirhynchia $\mathrm{cf}$. rastuensis (Benigni); Rhynchonella gr. quadrata Buckman = Quadratirhynchia? crassimedia (Buckman).

Later, Geyer and Hinkelbein (1974) found Rhynchonella wilfridi Jiménez de Cisneros, 1923 and Terebratulidae sp. indet. in grey to yellowish marls and limestones of the same locality. Rhynchonella wilfridi has been considered as synonymous of Prionorhynchia quinqueplicata (Zieten) by Alméras et al. (1993), Baeza-Carratalá et al. (2004) and Baeza-Carratalá (2008). As indicated above, this species has a stratigraphic range restricted to the Upper Pliensbachian in the Eastern Subbetic and other areas of Western Tethys. This age is supported by the ammonite fauna recorded by Geyer and Hinkelbein (op. cit.) composed by the genera Arieticeras/Canavaria/Fontanelliceras, Lioceratoides and Catacoeloceras.

The same authors (Geyer and Hinkelbein, 1974) in a nearby locality within the Morrón de Totana Unit, reported a tract with brachiopods stratigraphically above the previously described, consisting also of grey to yellowish marls and limestones but partially nodular and with ferruginous oolites. They identified "Rhynchonella" ssp., Spiriferina alpina (=Liospiriferina alpina) and Spiriferina angulata (=Cisnerospira angulata), together with an ammonite association comprising Lytoceras sp. ex. gr. sepositum Meneghini, Peronoceras cf. millarense Monestier, Catacoeloceras tethysi Géczy, Arieticeras sp., Hildoceras cf. bifrons (Bruguière), and $H$. cf. graecum Renz. In this assemblage species from the Early and Middle Toarcian appear, hence the authors admitted a certain condensation in these levels. This condensation agrees with the brachiopod data, since Liospiriferina alpina and Cisnerospira angulata, though ranging until the earliest
Toarcian in some areas, do not surpass the Early Toarcian Mass Extinction Event at the base of the Serpentinum (=Falciferum) Zone. This event marks the final extinction of the order Spiriferinida (cf. Comas-Rengifo et al., 2006; García Joral et al., 2011). The co-occurrences of these species with $H$. bifrons from the Middle Toarcian is thus likely related to temporal averaging of Early and Middle Toarcian specimens.

\subsection{Perona Section}

The brachiopods were collected in two beds (Pe-1 and Pe-2), within a tract of yellowish marly limestones that alternates with silty limestones, occasionally slightly nodular. In both beds, the assemblages are clearly dominated by Soaresirhynchia bouchardi (Davidson), with a few accompanying species.

The specimens of Soaresirhynchia bouchardi collected in this locality show high morphological variability displayed elsewhere in neighbouring basins, so that it is possible to recognize the distinct morphotypes (calva, penichensis, flamandi) that were described by several authors and sometimes considered to represent different species (Dubar, 1931; Rousselle, 1978; Alméras, 1994, Alméras and Fauré, 2000; Alméras et al., 2007, 2010 among others). However, no boundaries between the morphogroups are recognizable and the collected specimens have been assigned to a single species, following the same criteria considered in Comas-Rengifo and Goy (1975), García Joral and Goy (2000) or García Joral et al. (2011).

Other brachiopod taxa identified in Pe-1 bed are: Pseudogibbirhynchia sp. (a single large-sized specimen with the bifurcated rounded ribs typical of this genus but not assignable to any known species), Homoeorhynchia sp., Telothyris jauberti (Deslongchamps), and T. pyrenaica (Dubar).

In the Pe-2 bed, Soaresirhynchia bouchardi is found together with Prionorhynchia aff. msougari Rousselle - a single specimen, very similar to the Moroccan specimens of the species figured by Alméras et al. (1993) -, Prionorhynchia sp., Pseudogibbirhynchia jurensis (Quenstedt), and Telothyris pyrenaica (Dubar).

These brachiopods were collected in the same levels where Caracuel et al. (2006) identified Dactylioceras (Eodactylites) sp. and Hildaites striatus Guex, that characterize the Polymorphum and Serpentinum Zones of the Early Toarcian. An age restricted to the Serpentinum Zone can now be proposed for these levels, since the brachiopod assemblages found in Pe-1 and Pe-2 beds never occur below the Serpentinum Zone in the neighbouring basins. Soaresirhynchia bouchardi characterizes the El- 
egantulum Subzone of the Serpentinum Zone in the Iberian Range (García Joral and Goy, 2000), having a similar range in other basins, from southern England to Morocco and from Portugal to the Balkans (Ager, 1962; Rousselle, 1973; Alméras, 1994; Gakovic and Tchoumatchenco, 1994; Alméras and Fauré, 2000; Graziano et al., 2006; Alméras et al., 2007, 2010). This species has been recognized in a similar stratigraphic position in other areas of the Betic Range, such as Mallorca Island (Álvaro et al., 1989), or the eastern Subbetic (Baeza-Carratalá, 2008).

Pseudogibbirhynchia jurensis and Telothyris jauberti are recorded in the Iberian Range in the Serpentinum Zone, and T. pyrenaica is recorded both in the Serpentinum and in the Bifrons Zones (García Joral and Goy, 2000). A similar distribution is observed for these taxa in other regions of Western Tethys (cf. Alméras et al., 2007, 2010; García Joral et al., 2011 for a revision). Prionorhynchia msougari is recorded in the Middle-Upper Toarcian of the High Atlas (Rousselle, 1973; Alméras et al., 1993) and from the Lower Toarcian of Western Algeria, where it is found with species of the genera Soaresirhynchia and Telothyris (Alméras et al., 2007).

Besides these assemblages of Early Toarcian age, Paquet (1969) described a brachiopod assemblage in red ferruginous detritic limestones assigned to the Early Pliensbachian. The taxa represented in this assemblage are Spiriferina adscendens Deslongchanmps $\equiv$ Cisnerospira aff. adscendens (Deslongchanmps), Spiriferina gr. haueri Suess, Spiriferina falloti? Corroy - globose and slightly uniplicate, probably conspecific with the specimens considered in this work as Liospiriferina rostrata-, Rhynchonella curviceps Quenstedt $\equiv$ Gibbirhynchia curviceps (Quenstedt), Rhynchonella sp., Zeilleria roemeri Schlotheim, and Z. cf. roemeri. Some of these taxa had very wide geographical and stratigraphical distributions, although $G$. curviceps and $Z$. roemeri mainly occured in the Late Sinemurian and the Early Pliensbachian (cf. Alméras and Fauré, 2000; Elmi et al., 2003; Alméras et al., 2007; cf. Baeza-Carratalá, 2008).

\section{Brachiopod Assemblages}

Brachiopod assemblages from the Morrón de Totana and Perona Units can be subdivided into three major groups with temporal and paleobiogeographical significance:

MT1 Assemblage: It occurs in the Morrón de Totana Unit and is recorded in the Tres Carrascas, Malvariche and Prat Mayor Sections. It is dominated by large-sized Prionorhynchia specimens, and by smooth-shelled spiriferinids. Intraplicate terebratulids and axiniform zeillerids are scarce (Fig. 4). The taxa represented in this assemblage are characteristic of the Late Pliensbachian of the Mediterranean Province. An analogous assemblage has been reported in a similar stratigraphic position in the Eastern Subbetic (Baeza-Carratalá, 2008).

This assemblage can be subdivided in three biostratigraphically successive subassemblages:

MTla sub-assemblage: It consists of Cuneirhynchia cf. rastuensis, Quadratirhynchia? crassimedia, Liospiriferina rostrata, L. alpina, L. cf. cantianensis?, L. appenninica, L. sp. aff. decipiens, Callospiriferina? cf. gibba, Eplenyithyris cerasulum, and Zeilleria sp. This sub-assemblage occurs in the Algovianum Zone in Prat Mayor area.

MT1b sub-assemblage: It consists of Prionorhynchia polyptycha, P. quinqueplicata, Liospiriferina cf. alpina, and $L$. rostrata. It occurs in the Emaciatum Zone, Solare Subzone in the Tres Carrascas Section.

MTlc sub-assemblage: It consists of Prionorhynchia polyptycha, P. quinqueplicata, P. gignouxi, Quadratirhynchia? crassimedia, Liospiriferina rostrata, $L$. cf. gryphoidea, Callospiriferina tumida, Rhapidothyris delorenzoi, Lobothyris cf. punctata, and Securina? oxygonia. This sub-assemblage occurs in the Emaciatum Zone, Elisa Subzone, in the Tres Carrascas Section.

P1 Assemblage: It occurs at the base of the Perona Unit, and is composed of Gibbirhynchia curviceps, Cisnerospira aff. adscendens, Spiriferina gr. haueri, Liospiriferina rostrata, and Zeilleria roemeri. This assemblage characterizes the latest Sinemurian - Early Pliensbachian. From the paleobiogeographic point of view it is not well defined since most of the taxa forming this assemblage are cosmopolitan.

P2 Assemblage: It occurs in the Perona Unit. The most abundant species is Soaresirhynchia bouchardi. Less common taxa are represented by Prionorhynchia aff. msougari, Pseudogibbirhynchia jurensis, P. sp., Homoeorhynchia sp., Telothyris jauberti, and T. pyrenaica. The taxa represented in this assemblage are characteristic of the Serpentinum Zone of the Lower Toarcian in a wide area of the Western Tethys, including both NorthwestEuropean and Mediterranean regions.

\section{Contributions to Paleogeography and Paleobiogeography}

The paleogeographical context for the Jurassic of Sierra Espuña has been thoroughly studied (e.g.: Martín-Martín, 1996; Martín-Martín et al., 2006; Caracuel et al., 2006). At the beginning of the Jurassic, this area was located near the southern margin of the AlKaPeCa Microplate 


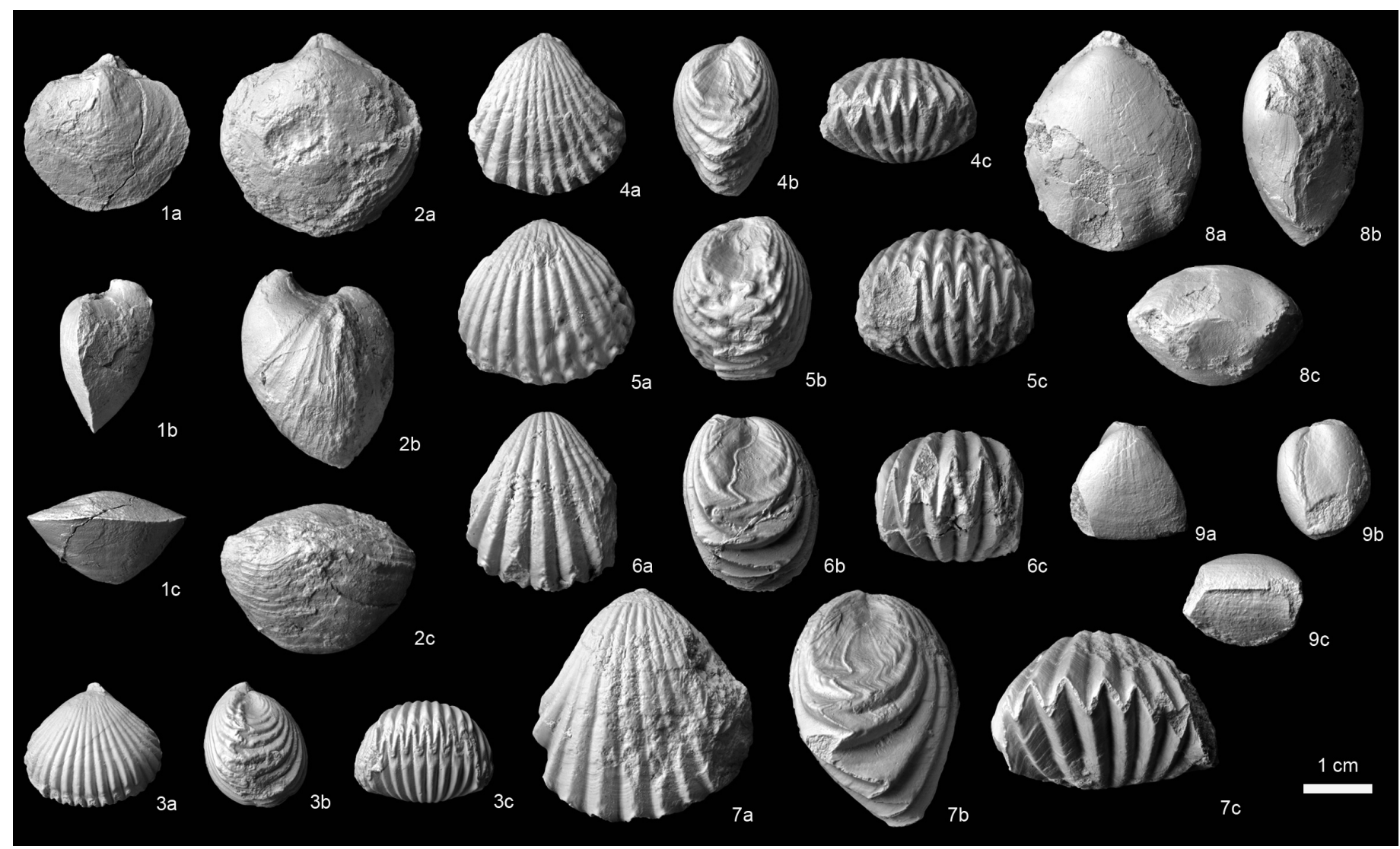

Fig. 4.- (next page). Some representative species of MT1 Assemblage from Sierra Espuña. 1: Liospiriferina alpina (Oppel, 1861). Specimen Ma.Sa.01 from the Algovianum Zone of the Malvariche Section. 2. Liospiriferina cf. rostrata (Schlotheim, 1822). Specimen TC.100C.Ls.01 from the Emaciatum Zone (Solare Subzone) of the Tres Carrascas Section. 3. Quadratirhynchia? crassimedia (Buckman, 1918). Specimen TC.100A.Qc.01 from the Emaciatum Zone (Elisa Subzone) of the Tres Carrascas Section. 4. Prionorhynchia polyptycha (Oppel, 1861). Specimen TC.100A.Pp.01 from the Emaciatum Zone (Elisa Subzone) of the Tres Carrascas Section. 5. Prionorhynchia gignouxi (Jiménez de Cisneros, 1923). Specimen TC.100A.Pg.01 from the Emaciatum Zone (Elisa Subzone) of the Tres Carrascas Section. 6. Prionorhynchia quinqueplicata (Zieten, 1832), Specimen TC.100A.Pq.01 from the Emaciatum Zone (Elisa Subzone) of the Tres Carrascas Section. 7. Prionorhynchia quinqueplicata (Zieten, 1832). Specimen TC.100C.Pq.01 from the Emaciatum Zone (Solare Subzone) of the Tres Carrascas Section. 8. Rhapidothyris delorenzoi (Böse, 1900). Specimen TC.100A.Rd.01 from the Emaciatum Zone (Elisa Subzone) of the Tres Carrascas Section. 9. Securina? oxygonia (Uhlig, 1880). Specimen TC.100A.So.01 from the Emaciatum Zone (Elisa Subzone) of the Tres Carrascas Section. (a=dorsal view, $\mathrm{b}=$ lateral view, and $\mathrm{c}=$ anterior view). Specimens stored in the collections of the Department of Earth and Environmental Sciences of the University of Alicante. All photographs (X1).

Fig. 4.- (página siguiente). Especies representativas de la asociación MT1 de Sierra Espuña. 1: Liospiriferina alpina (Oppel, 1861). Ejemplar Ma.Sa.01 (Zona Algovianum) procedente de la Sección de Malvariche. 2. Liospiriferina cf. rostrata (Schlotheim, 1822). Ejemplar TC.100C. Ls.01 (Zona Emaciatum, Subzona Solare) procedente de la Sección de Tres Carrascas. 3. Quadratirhynchia? crassimedia (Buckman, 1918). Ejemplar TC.100A.Qc.01 (Zona Emaciatum, Subzona Elisa) de la Sección de Tres Carrascas. 4. Prionorhynchia polyptycha (Oppel, 1861). Ejemplar TC.100A.Pp.01 (Zona Emaciatum, Subzona Elisa) de la Sección de Tres Carrascas. 5. Prionorhynchia gignouxi (Jiménez de Cisneros, 1923). Ejemplar TC.100A.Pg.01 (Zona Emaciatum, Subzona Elisa) de la Sección de Tres Carrascas. 6. Prionorhynchia quinqueplicata (Zieten, 1832), Ejemplar TC.100A.Pq.01 (Zona Emaciatum, Subzona Elisa) de la Sección de Tres Carrascas. 7. Prionorhynchia quinqueplicata (Zieten, 1832). Ejemplar TC.100C.Pq.01 (Zona Emaciatum, Subzona Solare) de la Sección de Tres Carrascas. 8. Rhapidothyris delorenzoi (Böse, 1900). Ejemplar TC.100A.Rd.01 (Zona Emaciatum, Subzona Elisa) de la Sección de Tres Carrascas. 9. Securina? oxygonia (Uhlig, 1880). Ejemplar TC.100A.So.01 (Zona Emaciatum, Subzona Elisa) de la Sección de Tres Carrascas. (a=vista dorsal, b=vista lateral y c=vista frontal). Los ejemplares figurados se encuentran depositados en las colecciones del Departamento de Ciencias de la Tierra y del Medio Ambiente de la UA. Todas las fotografías (X1).

(Alboran, Kabilyan, Peloritanian, and Calabria; Bouillin et al., 1986) as part of a shallow and restricted platform. This platform broke-up during the Early Jurassic, leading to an open shelf depositional environment with variable depth and a complex bottom due to block faulting and tilting (Martín-Martín et al., 2006).
From a paleobiogeographical point of view, this area was situated near the margins of Africa and Iberia (Martín-Algarra and Vera, 2004), close to the western boundary between the Mediterranean and the European Provinces (the latter also referred to as the Northwestern European) (cf. Ager, 1967, 1971, 1973; Vörös, 1977, 1984, 2002, 2005; Manceñido, 2002). 


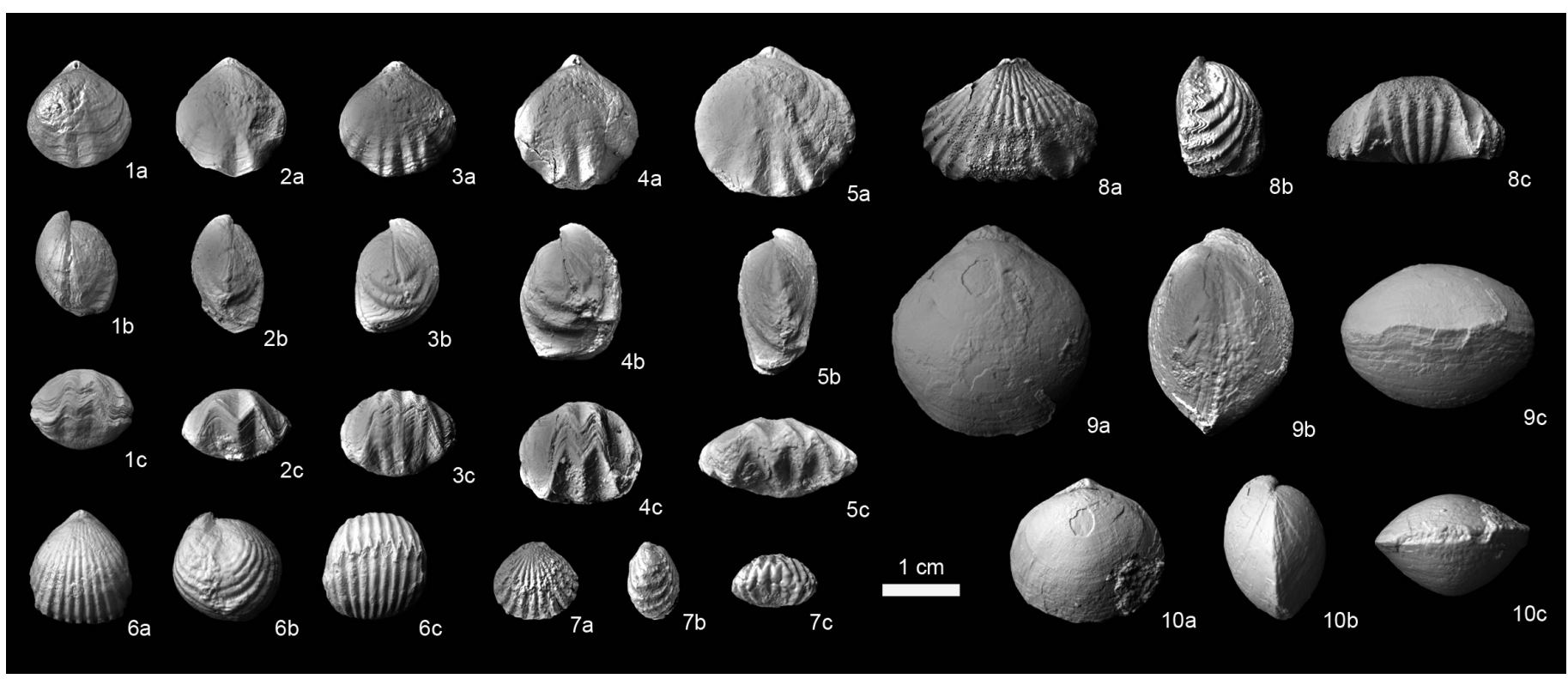

Fig. 5.- Some representative species of P2 Assemblage from Sierra Espuña. 1-5: Soaresirhynchia bouchardi (Davidson, 1852) from the Serpentinum Zone of the Perona Section.1: Specimen Pe-1.1, 2: Specimen Pe-1.2; 3: Specimen Pe-1.3; 4: Specimen Pe-1.4; 5: Specimen Pe-1.5. 6: Prionorhynchia aff. msougari Rousselle, 1973. Specimen Pe-2.Pm.01 from the Serpentinum Zone of the Perona Section. 7: Pseudogibirhynchia jurensis (Quenstedt, 1858). Specimen Pe-2.Pj.01 from the Serpentinum Zone of the Perona Section. 8: Pseudogibbirhynchia sp. Specimen Pe-1. Px.01, from the Serpentinum Zone of the Perona Section. 9: Telothyris jauberti (Deslongchamps, 1863). Specimen Pe-1.Tj.01 from the Serpentinum Zone of the Perona Section. 10: Telothyris pyrenaica (Dubar, 1931). Specimen Pe-1.Tp.01 from the Serpentinum Zone of the Perona Section. ( $\mathrm{a}=$ dorsal view, $\mathrm{b}=$ lateral view, and $\mathrm{c}=$ anterior view). Specimens stored in the collections of the Department of Earth and Environmental Sciences of the University of Alicante. All photographs (X1).

Fig. 5.- Especies representativas de la asociación P2 de Sierra Espuña. 1-5: Soaresirhynchia bouchardi (Davidson, 1852) de la Zona Serpentinum de la Sección de Perona. 1: Ejemplar Pe-1.1, 2: Ejemplar Pe-1.2; 3: Ejemplar Pe-1.3; 4: Ejemplar Pe-1.4; 5: Ejemplar Pe-1.5. 6: Prionorhynchia aff. msougari Rousselle, 1973. Ejemplar Pe-2.Pm.01, de la Zona Serpentinum de la Sección de Perona. 7: Pseudogibirhynchia jurensis (Quenstedt, 1858). Ejemplar Pe-2.Pj.01, de la Zona Serpentinum de la Sección de Perona. 8: Pseudogibbirhynchia sp. Ejemplar Pe-1.Px.01, de la Zona Serpentinum de la Sección de Perona. 9: Telothyris jauberti (Deslongchamps, 1863). Ejemplar Pe-1.Tj.01, de la Zona Serpentinum de la Sección de Perona. 10: Telothyris pyrenaica (Dubar, 1931). Ejemplar Pe-1.Tp.01, de la Zona Serpentinum de la Sección de Perona. (a=vista dorsal, $\mathrm{b}=$ vista lateral y $\mathrm{c}=$ vista frontal). Los ejemplares figurados se encuentran depositados en las colecciones del Departamento de Ciencias de la Tierra y del Medio Ambiente de la UA. Todas las fotografías (X1).

\begin{tabular}{|c|c|c|c|c|c|}
\hline Assemblage & $\begin{array}{c}\text { Eastern Subbetic } \\
\text { (Baeza-Carratalá, } \\
\text { 2008) }\end{array}$ & $\begin{array}{c}\text { Bakony } \\
\text { (Vörös, 2009) }\end{array}$ & $\begin{array}{c}\text { Western Algeria } \\
\text { (Alméras et al., } \\
\text { 2007) }\end{array}$ & $\begin{array}{l}\text { Iberian Range } \\
\text { (Comas-Rengifo, } \\
\text { 1992; García Joral } \\
\text { and Goy, 2000) }\end{array}$ & $\begin{array}{l}\text { Pyrennees } \\
\text { (Alméras and } \\
\text { Fauré, 2000) }\end{array}$ \\
\hline MT1 $(\mathrm{NT}=17)$ & $14(82 \%)$ & $8(47 \%)$ & $4(23,5 \%)$ & $4(23,5 \%)$ & $4(23,5 \%)$ \\
\hline $\operatorname{Pe} 1(\mathrm{NT}=5)$ & $4(80 \%)$ & $1(20 \%)$ & $3(60 \%)$ & $3(60 \%)$ & $3(60 \%)$ \\
\hline $\mathrm{Pe} 2(\mathrm{NT}=7)$ & $2(28,5 \%)$ & $0(0 \%)$ & $5(71 \%)$ & $4(57 \%)$ & $4(57 \%)$ \\
\hline
\end{tabular}

Table 2. Comparison of shared species in the brachiopod assemblages recognized in the Sierra Espuña and other representative areas of Western Tethys, in total number and percentages.

Tabla 2. Número y porcentaje de especies de las asociaciones de braquiópodos reconocidas en Sierra Espuña presentes en otras áreas representativas del Tethys occidental.

The brachiopod assemblages described in this paper indicate that the two tectonic Units of the Malaguide complex differed in their paleobiogeographic affinity.

In the Morrón de Totana Unit, assemblage MT1 has clear Mediterranean affinities, with a high percentage of species $(82 \%)$ also found in the eastern Subbetic and in other typical Mediterranean domains as Bakony Moun- tains $(47 \%)$, whereas this affinity is low $(23,5 \%)$ when compared with European domains (Iberian Range and Pyrenees) and with the African margin (Table 2). Moreover, three of the four species shared with European regions (Liospiriferina alpina, L. rostrata and Lobothyris punctata) can be considered ubiquitous, and are also found in the Mediterranean Province. The fourth, Cal- 
lospiriferina tumida, considered properly European, has been however also reported in the eastern Subbetic (Baeza-Carratalá, 2008).

The two assemblages described in the Perona Unit are not so clearly related to the Mediterranean Province (Table 2). P1 is composed by widely distributed species. The most representative taxa are Liospiriferina rostrata, Gibbirhynchia curviceps, Zeilleria roemeri, and Cisnerospira aff. adscendens. The three former species are present in the Pyrenees, the Iberian Range, the Betic Ranges and Western Algeria, whereas only the ubiquitous G. curviceps is reported also in the Bakony. Cisnerospira aff. adscendens seems to be endemic to the Betic area. The absence of the typical taxa of the Mediterranean Early Pliensbachian (Apringia, Pisirhynchia, Linguithyris, etc.) or even of the taxa that characterized this interval in the eastern Subbetic (Tauromenia, Lychnothyris, Praesphaeroidothyris, Securina; cf. Baeza-Carratalá, 2011; BaezaCarratalá and García Joral, in press) suggests a closer relation of this assemblage with those of the European and African margin than with the faunas characteristic of the Mediterranean Province. P1 Assemblage come from red ferruginous detritic limestones, probably deposited in slightly more "epicontinental" conditions than the ferruginous silty limestones with Fe-oolites from which MT1 assemblage comes.

Having in mind that the available paleogeographic data indicate proximity (Martín-Martín, 1996, estimated a distance of 10-12 km between the two tectonic units in the Early Jurassic) and that all the species in P1 assemblage also occurs in the eastern Subbetic (a paleomargin from a different subplate separated at least $500 \mathrm{~km}$ from Sierra Espuña; cf. Martín-Algarra and Vera, 2004), the differences in taxonomical composition could be related to paleoenvironmental differences. The Perona Unit probably corresponds to environments more influenced by continental areas than in the Morrón de Totana Unit and in the eastern Subbetic, where thicker, more pelagic and with higher deeping rate succesions are represented.

P2 Assemblage is characteristic of the Spanish Province (Choffat, 1880, Dubar, 1931, Delance, 1972, García Joral and Goy, 1984, 2004) that builds up in the Westernmost Tethys after the provincialism fades as a consequence of the Early Toarcian Mass Extinction Event (ETMEE). The ecological void caused by the ETMEE in both European and Mediterranean areas was filled in by Soaresirhynchia bouchardi in the aftermath of the Extinction, a species with opportunist features (García Joral and Goy, 2000; Gahr, 2005, García Joral et al., 2011), and later on by other species, Homoeorhynchia and Telothyris being the more representative genera. S. bouchardi extends over a wide area of Western Tethys, as stated earlier, whereas the subsequent assemblage is more restricted to westernmost areas, including the Andean Region in South America (Manceñido, 2002). The development of the Spanish Province lasts only until the Aalenian, when the former European - Mediterranean paleobiogeographical pattern is re-established.

The taxa of the Spanish Province have not been described in the core areas of the Mediterranean province, such as in the Southern Alps, Transdanubian Ranges or Sicily. Thus, the Spanish Province can be considered as "marginal" in the Tethyan areas, though the absence of its taxa might also be a consequence of worse preservation conditions. A particularity of P2 Assemblage is the occurrence of Prionorhynchia aff. msougari. This species has not been found in the European domains of the Spanish Province, but they have been reported in Morocco (Rousselle, 1973) and Algeria (Alméras et al., 1993, 2007). This suggests that P2 Assemblage might be more linked to the African margin than to the European one.

The paleobiogeographical and paleoecological differences established between the Morrón de Totana and the Perona Units based on their brachiopod assemblages are in good accordance with the geodynamic structural model of the Sierra Espuña area (Martín-Martín, 1996; Martín-Martín and Martín-Algarra, 1997), in which the Perona Unit was placed not far away, but in a more southern position than the Morrón de Totana Unit.

\section{Conclusions}

The Sierra Espuña area has yielded the only Jurassic brachiopod record from the Internal Zones of the Betic Cordillera. Their description increases notably the knowledge of the group in the paleomargin of AlKaPeCa microplate, where until now only the Algerian Tell brachiopods had been described. The studied specimens have been assigned to 28 species belonging to 17 genera. Prionorhynchia aff. msougari is identified for the first time in the Iberian Peninsula.

Three assemblages were recognised on the basis of the specimens collected in the two tectonic units defined for this region: the Morrón de Totana Unit (MT1) and the Perona Unit (P1 and P2). MT1 Assemblage has a Late Pliensbachian age and shows clear Mediterranean affinities. P1 Assemblage is of Latest Sinemurian - Early Pliensbachian age, and is mostly constituted by ubiquitous taxa. P2 Assemblage belongs to the Spanish Province that builds up after the Early Toarcian Mass Extinction Event, occupying a wider area of the westernmost Tethys. The occurrence in this assemblage of Priono- 
rhynchia aff. msougari suggests a closer connection of the Perona Unit to the African areas than to the European within the Spanish Province.

The paleobiogeographical affinities of these brachiopod assemblages agrees with the geodynamic stucturing model of the Sierra Espuña area, that implies a relative more southern position for the Perona Unit. From the brachiopod assemblages a more marginal position, close to the epicontinental areas, is inferred for this unit.

\section{Acknowledgements}

This work is dedicated to the memory of Jesús Caracuel. We are indebted to Gloria Espinosa who allowed us to review Dr. Caracuel's notes. The present research is supported by Research Group VIGROB-167 (University of Alicante), and by research projects CGL2009-07830/ BTE, CGL 2008-03112 and CGL 2008-01273 of the Spanish Ministerio de Educación y Ciencia, and project GR58/08B/910431 of the Universidad Complutense de Madrid. We gratefully acknowledge the reviewers, Dr. Attila Vörös, Dr. M. Siblík, and Dr. A. Tomaśových for their thorough reviews and supportive comments and Dr. J. López-Gómez for editorial comments. We thank Dr. M. Martín-Martín for his help locating the outcrops and reviewing the first draft of this manuscript.

\section{References}

Ager, D.V. (1956): A monograph of the British Liassic Rhynchonellidae. Part. I. Monograph of the Palaeontographical Society, London 110: $50 \mathrm{p}$.

Ager, D.V. (1962): A monograph of the British Liassic Rhynchonellidae. Part. III. Monograph of the Palaeontographical Society, London 116: 85-136.

Ager, D.V. (1967): Some Mesozoic Brachiopods in the Tethys region. In: C.G. Adams, D.V. Ager (eds.), Aspects of Tethyan Biogeography. Systematics Association Publication 7: 135151.

Ager, D.V. (1971): Space and time in brachiopod history. In: F. Middlemiss, P. Rawson, G. Newall (eds.), Faunal Provinces in Space and Time. Geological Journal Special Issue 4: 95-110.

Ager, D.V. (1973): Mesozoic Brachiopoda. In: A. Hallam (ed.), Atlas of Palaeobiogeography, Elsevier, Amsterdam: 431 - 436.

Alméras, Y. (1964): Brachiopodes du Lias et du Dogger. Documents des Laboratoires de Géologie de la Faculté des Sciencies de Lyon 5: 1-161.

Alméras, Y. (1994): Le genre Soaresirhynchia nov. (Brachiopoda, Rhynchonellacea, Wellerellidae) dans le Toarcien du sous-bassin nord-lusitanien (Portugal). Documents des Laboratoires de Géologie Lyon 130: 1-135.

Alméras, Y., Becaud, M., Cougnon, M. (2010): Brachiopodes liasiques de la bordure sud du Massif armoricain. Bulletin de la Société des Sciences Naturelles de l'Ouest de la France supplément hors-série: 1-131.

Alméras, Y., Ameur, M., Elmi, S. (1993): Prionorhynchia regia (Rothpletz), Rhynchonellidé du Lias maghrebin et Evolution du genre Prionorhynchia Buckman. Bollettino della Società Paleontologica Italiana 32 (1), 59-77.

Alméras, Y., Fauré, P. (2000): Les Brachiopodes liasiques des Pyrénées. Paléontologie, Biostratigraphie, Paléobiogéographie et Paléoenvironnements. Strata 36, 1-395.

Alméras, Y., Elmi, S., Fauré, P. (2007): Les Brachiopodes Liasiques d'Algerie Occidentale. Documents des Laboratoires de Géologie Lyon 163: 3-241.

Álvaro, M., Barnolas, A., Cabra, P., Comas-Rengifo, M.J., Fernández-López, S.R., Goy, A. (1989): El Jurásico de Mallorca (Islas Baleares). Cuadernos de Geología Ibérica 13, 67-120.

Baeza-Carratalá, J.F. (2008): Patrimonio paleontológico en la colección Jiménez de Cisneros y su aplicación al estudio de los braquiópodos del Jurásico Inferior en la Cordillera Bética Oriental (provincias Alicante y Norte de Murcia). Unpublished Doctoral Thesis, Universidad Alicante: 906 p.

Baeza-Carratalá, J.F. (2010): Nuevos datos para la determinación sistemática de Rhapidothyris delorenzoi (Böse, 1900). Un Loboidothyridoidea (Brachiopoda) del Jurásico Inferior mediterráneo. Boletín de la Real Sociedad Española de Historia Natural, Sección Geológica 104, 37-45.

Baeza-Carratalá, J.F. (2011): New Early Jurassic brachiopods from the Western Tethys (Eastern Subbetic, Spain) and their systematic and paleobiogeographic affinities. Geobios 44, 345-360. doi: 10.1016/j.geobios.2010.09.003.

Baeza-Carratalá, J.F., García Joral, F. (in press): Multicostate zeillerids (Brachiopoda, Terebratulida) from the Lower Jurassic of the Eastern Subbetic (SE Spain) and their use in correlation and paleobiogeography. Geologica Acta. doi: 10.1344/105000001699.

Baeza-Carratalá, J.F., Dulai, A., Vörös A. (2004): Revisión sistemática de la Fauna de Braquiópodos del Rincón de Egea. In: IGME, Universidad de Alicante (eds.), Libro Homenaje a Daniel Jiménez de Cisneros y Hervás: 217-222.

Bassoullet, J.P., Elmi, S., Poisson, A., Ricou, L.E., Cecca, F., Bellión, Y., Giraud, R., Baudin, F. (1993): Middle Toarcian (184-182 Ma.). In: J. Dercourt, L.E. Ricou, B. Vrielynck (eds.), Atlas Tethys Palaeoenviromental Maps. Beicip-Franlab, Rueil-Malmaison.

Bouillin, J.P., Durand-Delga, M., Olivier, O. (1986): Betic, Rifean and Tyrrhenian arcs: distinctive features, genesis and development. In: F.C. Wezel (ed.), Origin of Arcs, Elsevier: 281-304.

Caracuel, J.E., Sandoval, J., Martín-Martín, M., Estévez, A., Martín-Rojas, I. (2006): Jurassic biostratigraphy and paleoenvironmental evolution of the Maláguide Complex from Sierra Espuña (Internal Betic Zone, SE Spain). Geobios 39, 25-42. doi: 10.1016/j.geobios.2004.09.002

Cariou, E., Hantzpergue, P. (1997): Groupe Français dÉtudes du Jurassique, biostratigraphie du Jurassique ouest-européen et méditerranéen. Zonations parallèles et distribution des invertébrés et microfossiles. Bulletin des Centres de Recherches-Exploration Production dElf-Aquitaine 17, 1-400. 
Choffat, P. (1880): Etude stratigraphique et paléontologique des terrains jurassiques du Portugal. lère livraison: Le Lias et le Dogger au Nord du Tage. Mémoire du Service des Travaux Géologiques de Portugal: $72 \mathrm{p}$.

Comas-Rengifo, M.J., García Joral, F., Goy, A. (2006): Spiriferinida (Brachiopoda) del Jurásico Inferior del NE y N de España: distribución y extinción durante el evento anóxico oceánico del Toarciense inferior. Boletín de la Real Sociedad Española de Historia Natural, Sección Geológica, 101, 147-157.

Comas-Rengifo, M.J., Goy, A. (1975): Estratigrafía y Paleontología del Jurásico de Ribarredonda (Guadalajara). Estudios Geológicos 31, 297-339.

Delance, J.H. (1972): Problèmes posés par la variation géographique des espèces, leurs implications stratigraphiques. Exemples pris chez les brachiopodes jurassiques. Mémoires du B.R.G.M. 77, 69-76.

Dubar, G. (1931): Brachiopodes liasiques de Catalogne et des régions voisines. Butlletí de la Institució Catalana d'Historia Natural 31 (4), 103-180.

Elmi, S., Alméras, Y., Benhamou, M., Mekahli, L., Marok, A. (2003): Biostratigraphie des brachiopodes et âge Carixien (Pliensbachien inférieur) des calcaries à grands bivalves en Algérie occidentale. Geobios 36, 695-706. doi:10.1016/j. geobios.2003.03.005.

Fallot, P. (1945): Estudios geológicos en la Zona Subbética entre Alicante y el río Guadiana Menor. Monografías del Consejo Superior de Investigaciones Científicas, Instituto Lucas Mallada 5, 1-719.

Gahr, M. (2005): Response of Lower Toarcian (Lower Jurassic) macrobenthos of the Iberian Peninsula to sea level changes and mass extinction. Journal of Iberian Geology 31, 197-215.

Gakovic, M., Tchoumatchenco, P. (1994): Jurassic brachiopods from the Dinarides (NE Herzegovina). Geologica Balcanica 24 (3), 13-29.

García Joral, F., Gómez, J.J., Goy, A. (2011): Mass extinction and recovery of the Early Toarcian (Early Jurassic) brachiopods linked to climate change in northern and central Spain. Palaeogeography, Palaeoclimatology, Palaeoecology 302, 367-380.

García Joral, F., Goy, A. (1984): Características de la fauna de braquiópodos del Toarciense Superior en el Sector Central de la Cordillera Ibérica (Noreste de España). Estudios Geológi$\cos 40,55-60$.

García Joral, F., Goy, A. (2000): Stratigraphic distribution of Toarcian brachiopods from the Iberian Range and its relation to depositional sequences. Geo-Research Forum 6, 381-386.

García Joral, F., Goy, A. (2004): Caracterización de Choffatirhynchia nov. gen. (Brachiopoda, Rhynchonellida) en el Toarciense (Jurásico) de la Cordillera Ibérica (España). Boletín de la Real Sociedad de Historia Natural, Sección Geológica 99 (1-4), 237-250.

Geyer, O.F., Hinkelbein, K. (1974): Las Oolitas ferruginosas del Jurásico de la Sierra de Espuña (prov. de Murcia). Acta Geológica Hispánica 9-3, 102-106.
Graziano, R., Buono, G., Taddei Ruggiero, E. (2006): Lower Toarcian (Jurassic) brachiopod-rich carbonate facies of the Gran Sasso range (central Apennines, Italy). Bolletino della Societá Paleontologica Italiana 45, 61-74.

Guerrera, F., Martín-Algarra, A., Perrone, V. (1993): Late Oligocene-Miocene syn-/late-orogenic successions in Western and Central Mediterranean chains from Betic Cordillerra to Southern Apennines. Terranova 5, 525-544. doi:10.1111/j.1365-3121.1993.tb00302.x

Iñesta, M. (1988): Braquiópodos Liásicos del Cerro de La Cruz (La Romana, Prov. Alicante, España). Mediterránea, Serie Geológica 7, 45-64.

Jiménez de Cisneros, D. (1923): La Fauna de los estratos de "Pygope Aspasia" Menegh. del Liásico Medio del Rincón de Egea en el W. de la provincia de Murcia. Junta para Ampliación de Estudios e Investigaciones Científicas. Trabajos del Museo Nacional de Ciencias Naturales, Serie Geológica 30: 55 p.

Kampschuur, W., Langeberg, C.W., Baena, J., Velando, F., García-Monzón, G., Paquet, J., Rondeel, H.E. (1972): Hoja Geológica num. 932 (Coy). Mapa Geológico de España E. 1:50.000. I.G.M.E., Madrid.

Maaté, A. (1996): Estratigrafía y Evolución Paleogeográfica alpina del Dominio Gomáride (Rif Interno, Marruecos). Doctoral Thesis, Universidad de Granada: 399 p.

Manceñido, M.O. (2002): Paleobiogeography of Mesozoic brachiopod faunas from Andean-Patagonian areas in a global context. Geobios 35 (M.S. 24), 176-192.

Martín-Algarra, A., Ruiz-Ortiz, P.A., Vera, J.A. (1992): Factors controlling Cretaceous turbidite deposition in the Betic Cordillera. Revista de la Sociedad Geológica de España 5, 53-80.

Martín-Algarra, A., Vera, J.A. (2004): La Cordillera Bética y las Baleares en el contexto del Mediterráneo Occidental. In: J.A. Vera (ed.), Geología de España, Sociedad Geológica de España, I.G.M.E: 352-354.

Martín-Martín, M. (1996): El Terciario del Dominio Maláguide en Sierra Espuña (Cordillera Bética oriental, SE España): Estratigrafía y Evolución Paleogeográfica. Doctoral Thesis, Universidad de Granada: 297 p.

Martín-Martín, M., Martín-Algarra, A. (1997): La estructura del área de Sierra Espuña (Contacto Zonas Internas-Externas, sector oriental de la Cordillera Bética). Estudios Geológicos 53, 237-248.

Martín-Martín, M., Martín-Rojas, I., Caracuel, J.E., Estévez, A., Martín-Algarra, A., Sandoval, J. (2006): Tectonic framework and extensional pattern of the Maláguide Complex from Sierra Espuña (Internal Betic Zone) during JurassicCretaceous: implications for the Westernmost Tethys geodynamic evolution. International Journal of Earth Sciencies (Geologishe Rundschau) 95, 815-826. doi: 10.1007/s00531005-0061-7.

Paquet, J. (1969): Étude géologique de l'Ouest de la province de Murcia (Espagne). Mémoires du Bureau de Recherches Géologiques et Minières 48 (111), Paris: $270 \mathrm{p}$.

Peyre, N., Peyre, Y., (1960): Observaciones Geológicas Sobre Sierra Espuña (Murcia). Notas y Comunicaciones del Insti- 
tuto Geológico y Minero de España 59, 3-23.

Rousselle, L. (1973): Le genre Prionorhynchia (Rhynchonellacea) dans le Toarcien et l'Aalénien inférieur du Haut-Atlas central et oriental. Notes et Mémoires du Service géologique du Maroc 34 (254), 135-149.

Rousselle, L. (1978): Polymorphisme phénotypique et spéciation chez Stolmorhynchia bouchardi (Davidson) s.l. (Brachiopoda, Rhynchonellacea) du Toarcien, en Europe et au Magreb. Compte rendu sommaire des séances de la Société Géologique de France 2, 75-78.

Sacchi Vialli, G., Cantaluppi, G. (1967): I nuovi fossili di Gozzano (Prealpi Piemontesi). Memorie della Società Italiana di Scienze Naturali 16(2), 63-127.

Sanz de Galdeano, C. (1997): La Zona Interna Bético-Rifeña. Monografías Tierras del Sur, Universidad de Granada: 316 p.

Stampfli, G.M., Borel, G.D. (2004): The TRANSMED transects in space and time: constraints on the paleotectonic evolution of the mediterranean domain. In: W. Cavazza, F.M. Roure, W. Spakman, G.M. Stampfli, P.A. Ziegler (eds.), The TRANSMED Atlas - The Mediterranean Region from Crust to Mantle. Springer, Berlin: 53-80 + CD-ROM.

Vera, J.A. (2001): Evolution of the South Iberian Continental margin. In: P.A. Ziegler, W. Cavazza, A.H.F. Robertson, S.
Crasquin- Soleau (eds.), Peri-Tethys Memoir 6: Peri-Thetyan Rift/ Wrench Basins and Passive Margins, Mém. Mus. Natl. Hist. Nat.: 109-143.

Vörös, A. (1977): Provinciality of the Mediterranean Lower Jurassic brachiopod fauna: causes and plate tectonic implications. Palaeogeography, Palaeoclimatology, Palaeoecology 21, 1-16.

Vörös, A. (1984): Lower and Middle Jurassic brachiopod provinces in the western Tethys. Annales Universitatis Scientiarum Budapestinensis de Rolando Eötvös nominatae, Sectio Geologica 24, 207-233.

Vörös, A. (2002): Victims of the Early Toarcian anoxic event: the radiation and extinction of Jurassic Koninckinidae (Brachiopoda). Lethaia 35, 345-357.

Vörös, A. (2005): The smooth brachiopods of the Mediterranean Jurassic: refugees or invaders? Palaeogeography, $\mathrm{Pa}$ laeoclimatology, Palaeoecology 223, 222-242.

Vörös, A. (2009): The Pliensbachian brachiopods of the Bakony Mountains (Hungary). Geologica Hungarica, series Paleontologica 58: $300 \mathrm{p}$.

Ziegler, P.A. (1990): Geological Atlas of Western and Central Europe. Shell International Petroleum. B.V. Maatschappij, Geological Society Publishing House, Bath: 1-239. 